\title{
Hemochromatosis type 4
}

INSERM

\section{Source}

INSERM. (1999). Orphanet: an online rare disease and orphan drug data base.

Hemochromatosis type 4. ORPHA:139491

Hemochromatosis type 4 (also called ferroportin disease) is a form of rare hereditary hemochromatosis $(\mathrm{HH}$; see this term), a group of diseases characterized by excessive tissue iron deposition of genetic origin. 